\title{
小アンカーをタンデムにつないだ係留 ラインの把駐力と型について
}

\author{
正員 桑 野 三 綱* \\ The Statical Holding Power and Forms of the Tandem Type Anchors on Dry Sand \\ by Mitsutsuna Kuwano Member
}

\section{Summary}

In this paper, the statical holding power and forms of the tandem type anchors on dry sand are investigated theoretically and experimentally.

Tandem type anchor consist of a considerable number of small unit anchors, these small unit anchor has some flukes around shank and be connected tandem.

The results of experiment on dry sand are compared with those of calculation.

\section{1 楮}

船や浮遊式海洋構造物を海上に係留, 位置保持する場 合, 海中に抢ける係留ラインの挙動やアンカーの把駐力 については, 静的, 動的特性について多くの研究が行わ れている。しかし実䟢に係船する場合, アンカーの把駐 カが必ずしも信頼が置けず1)，その把駐力をおぎならた め, 海面状況に応じチェンの繰り出し長さを変えて, 海 底に横たわったチェンによる把駐力を増減させ，係留 イン全体の把駐力を保つような使い方が一般的である が, 海底に横たわった係留ラインの挙動に関して論じた ものは少ないよらである。

ここでは, 通常の係留ラインのアンカーと海底に横た わるチェンの部分を把駐力を持った小アンカーをタンデ ムに連結したタンデム式アンカーに怙きかえ, その海底 での静的特性を, 把駐力と必要長さと型の関連において 検討するとともに，畭燥砂中でのタンデム式アンカーの 簡単な実験と数値計算を行いそその結果を示す。

\section{2 タンデム式アンカー}

アンカーにはいろいろの種類があり，それぞれに特徵 があるが，アンカーはその使用目的により不特定な海底 土質に対し, 安定性, 高把駐性, 収納性, 耐久性, 操作 性等が重要な性能となる。

タンデム式アンカーとは Fig. 1 に示すように, 両端 に連結環を有するシャンクのまわりに数本の爪を配置し

$*$ (株) 白杵鉄工所

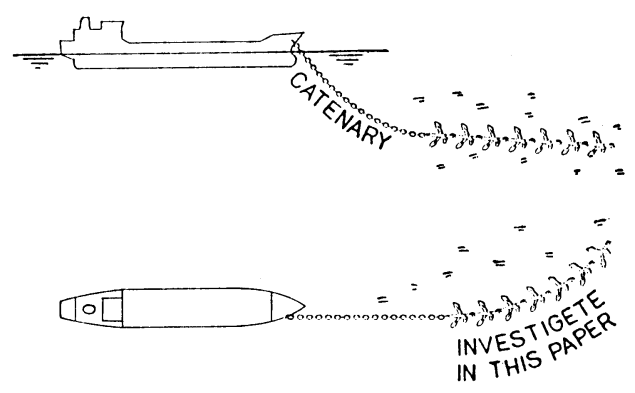

F.g. 1 Tandem type anchor

た小アンカーを多数タンデム式に連結したものであり， 個々のアンカーの把駐力は小さいが，全体として大きな 把駐力を得ようとするものである。

その特徵は,

1） アンカーが前後に引張られているために姿勢が安 定している。またシャンクを軸に回転しても把駐力 の変化は小さい。

2）海底に埋没していても 1 個ずつ引き出すために小 さい力で抜錨出来る。

3）把駐力が調整可能であり, 衝撃力が加わってもタ ンデム式アンカーの一部が持上がるか方向を変える ことによりダンピング効果を持つ。

4）海底で岩等に引掛った場合でも，爪の強度をチェ ンの破断力より小さくしておけば，爪が折れるだけ でフンカーの全損事故がなくなり, 把駐力が失われ ることはない。 
5）分解すれば取り扱いが簡単である。 等が考兄られ。

\section{3 タンテム式アンカーの静的特性}

\section{1 計算条件}

海底に横たわったタンデム式アンカーは，最初海底に 投下された状態から直線状に引張られ，ついで風や潮流 の変化により船の方向が変わったとき，曳きずられてあ る角度まで振られて釣合う。その時のタンデム式アンカ 一の形状, 張力, 長さの関係を求める。

計算には次の仮定をする。

1）タンデム式アンカーは完全に曲り易く、モーメン トは働かず, 伸びもなく曲線に近似出来る。

2）水平な海底の 2 次元運動であり，海底の凹凸や抗 力係数の変化はない。

3）タンデム式アンカーが振られて釣合った状態で, 小アンカーにはシャンク軸方向, およびシャンクに 直角方向に小アンカーの最大静止軸抗力, および最 大静止横抗力が働いており , 最大静止抗力以上の力 が働いた時は釣合うまで移動し，最大静止抗力と釣 合った所で安定する。

4）潮流，波等の他の力は働かないものとする。

\section{2 釣合方程式}

Fig. 2 のようにタンデム式アンカーがある曲線状に釣 合っているとき, 最初向いていた方向を $x$ 軸, 曲る方向 に $x$ 軸に直角に $y$ 軸，曲り始める位置を原点に取る。

A点に打ける微少長さ $\Delta S$ に働く力の釣合いを考兄 る。

Fig. 2 亿示すように記号を次のように定める。

$T_{0}:$ 原点に捛ける曲線の接線方向の張力。

$T:$ A点に打ける曲線の接線方向の張力。

$T_{1}: \mathrm{A}$ 点から (1/2) $\Delta S$ だけ原点から離れた点の曲 線の接線方向の張力。

$T_{2}: \mathrm{A}$ 点から (1/2) $\Delta S$ だけ原点に近い点の曲線の 接線方向の張力。

$\Delta T: T_{1}$ そ $T_{2}$ の張力の差

$\theta: \mathrm{A}$ 点に打数曲線の接線が $x$ 軸となす角度。

$\Delta \theta: T_{1}$ と $T_{2}$ が $x$ 軸となす角度の差。

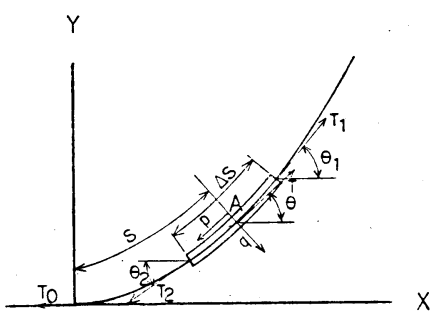

Fig. 2 Coordinate system $w:$ タンデム式アンカーの継手を含めた単位長さ当 りの平均重量。

$S:$ タンデム式アンカーの継手を含めた弦弧長さ。 $\Delta S:$ タンデム式アンカーの微少長さ。

$p:$ タンデム式アンカーの接線方向に $\Delta S$ に動く 抗力。

$q$ : タンデム式アンカーの法線方向に $\Delta S$ に働く 抗力。

$\Delta S$ に対する力の釣合方程式は次のようになる。 $x$ 軸方向の釣合方程式

$$
T_{1} \cos \theta_{1}+q \sin \theta-p \cos \theta-T_{2} \cos \theta_{2}=0
$$

$y$ 軸方向の釣合方程式

$$
T_{1} \sin \theta_{1}-q \cos \theta-p \sin \theta-T_{2} \sin \theta_{2}=0
$$

微少量を無視すると, $\Delta T, \Delta \theta$ は小さいので,

$$
\left.\begin{array}{ll}
T_{1}=T+(1 / 2) \Delta T & T_{2}=T-(1 / 2) \Delta T \\
\theta_{1}=\theta+(1 / 2) \Delta \theta & \theta_{2}=\theta-(1 / 2) \Delta \theta \\
\sin (1 / 2) \Delta \theta=(1 / 2) \Delta \theta & \cos (1 / 2) \Delta \theta=1
\end{array}\right\}
$$

と置ける。また

$$
p=\mu_{1} \Delta S w \quad q=\mu_{2} \Delta S w
$$

( $\mu_{1}:$ シャンク軸方向の抗力係数, $\mu_{2}$ : 横方向の抗力 係数), とすると

$$
\Delta S=\Delta x / \cos \theta
$$

なので（3)，（4)，（5）式を（1），(2）式に代入 して整理すると

$$
\Delta T \cos \theta-T \Delta \theta \sin \theta-\mu_{1} \Delta x w+\mu_{2} \Delta x w \tan \theta=0
$$

$$
\Delta T \sin \theta+T \Delta \theta \cos \theta-\mu_{1} \Delta x w \tan \theta-\mu_{2} \Delta x w=0
$$

となる。

$$
T_{0} / w=t_{0}, \quad T / w=t, \quad \Delta T / w=\Delta t, \quad S / l=s
$$

（l はタンデム式アンカーの単位長さ。）として無次元 化し，極限值を取ると，（6），(7) 式は

$$
\begin{aligned}
& \cos \theta d t-t \sin \theta d \theta-\left(\mu_{1}-\mu_{2} \tan \theta\right) d x=0 \\
& \sin \theta d t+t \cos \theta d \theta-\left(\mu_{1} \tan \theta+\mu_{2}\right) d x=0
\end{aligned}
$$

(8)，（9）式を $\theta=0$ で, $x=0, y=0, t=t_{0}$ の初期 条件で解くと

$$
\begin{aligned}
& t=t_{0} e^{\frac{\mu_{1}}{\mu_{2}} \theta} \\
& x=\frac{t_{0}}{\mu_{1}^{2}+\mu_{2}^{2}}\left\{\left(\mu_{1} \cos \theta+\mu_{2} \sin \theta\right) e^{\frac{\mu_{1}}{\mu_{2}} \theta}-\mu_{1}\right\} \\
& y=\frac{t_{0}}{\mu_{1}^{2}+\mu_{2}^{2}}\left\{\left(\mu_{1} \sin \theta-\mu_{2} \cos \theta\right) e^{\frac{\mu_{1}}{\mu_{2}} \theta}+\mu_{2}\right\} \\
& s=\frac{t_{0}}{\mu_{1}}\left(e^{\frac{\mu_{1}}{\mu_{2}} \theta}-1\right)
\end{aligned}
$$

となる。

種類の異なる数種類の係留ラインがつながっている場 合, 例えば Fig. 1 でチェンの部分が海底に横たわって曲 線の一部をなしている場合でも，チェンの長さと $\theta, t$ が 


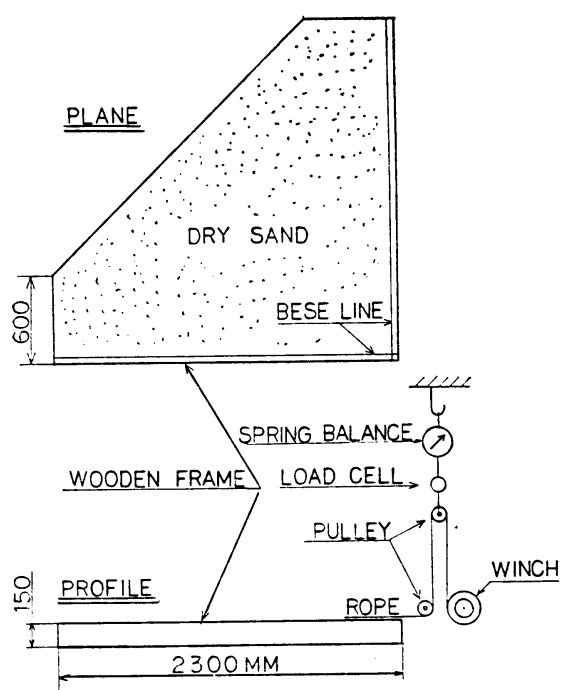

Fig. 3 Measuring apparatus

与えられれば, チェンの部分とタンデム式アンカーの部 分の接点で連続であるとして，チェンの $t_{0}$ をそのまま タンデム式アンカーの $\boldsymbol{t}$ として解けば, 一種類の場合と 同様にして解ける。

以上によりタンデム式アンカーの型が $\mathrm{A}$ 点の座標 $(x$, $y$ ) として求まり, 舷弧の長さ $s$, 張力 $t_{0}$ が求められる。

\section{4 実験と数值計算}

\section{1 实験装置}

Fig. 3 に示す実験装置を作り, Fig. 4 に示す 2 種類の タンデム式アンカーの模型について, 乾燥砂中における 曳引試験を行った。 A 型はマッシュルーム型, B型は三 本爪であり, 空中重量は 1 個 282.5 グラム, および 135.0 グラムである。直径 $8 \mathrm{~mm}$ の丸棒のシャンクに ナットで爪を取り付けてあり, 必要に応じ爪の交換が出 来るようになっている。各模型アンカーの間は釣系で $1 \mathrm{~cm}$ 間隔で連結されており, 曲り, 回転に対して自由 に動くようになっている。使用した砂は乾燥砂であり, その性状は Table 1 に示す。

実験中は適当に耕し表面をならした状態でアンカーを 曳引している。文献1)、2によると电引速度による把駐力 の影響はほとんどないようなので, 正確な速度制御は行

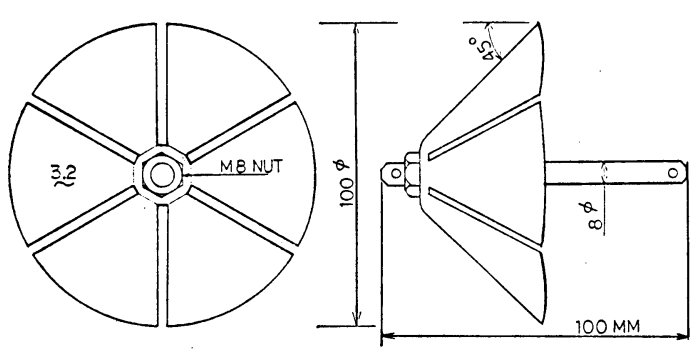

$$
\text { A - type }
$$

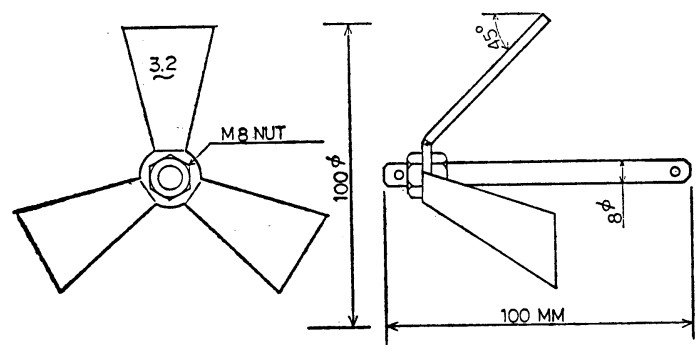

$$
\text { B - type }
$$

Fig. 4 Model anchor

っていないが，約 $1 \mathrm{~cm} / \mathrm{sec} \sim 2 \mathrm{~cm} / \mathrm{sec}$ の間で曳引してい る。張力の計測は Fig. 3 に示すごとく，バネ計りの下に バネワッシャを利用したロードセルを吊し，滑車を通し たロープで模型アンカーを曳引して計測している。

\section{$4.2 \mu_{1}, \mu_{2}$ の計測}

$\mu_{1}, \mu_{2}$ の計測は, 模型アンカーを1個から曳き始め, 8 個まで順次 1 個ずつ増していき, 各個数ごとに数回曳 引してその平均値を取った。計測する時は適度に曳引し て十分砂をかき込んだ後、静止した状態から動き始める 初頭の値を計測した。

$\mu_{2}$ を計測する時はワ状の木枠を天井から吊し模型ア ンカーの両端にゴムで約 $10 t$ の張力をかけると共に, 曳引棒から各模型アンカーの連結部に回転自由な環を釣 糸で結び, 全部のアンカーに同時に力が働くようにして 横方向に曳引している。

以上のようにして計測した計測結果を Fig. 5〜Fig. 8 に示す。その回㷌係数 (把駐係数=アンカー単体の乾燥 砂中の把駐力/アンカー単体の空中重量, に等しい)。 は, $\mathrm{A}$ 型で $\mu_{1}=9.219, \mu_{2}=1.270, \mathrm{~B}$ 型で爪の方向が

Table 1 Quality of dry sand

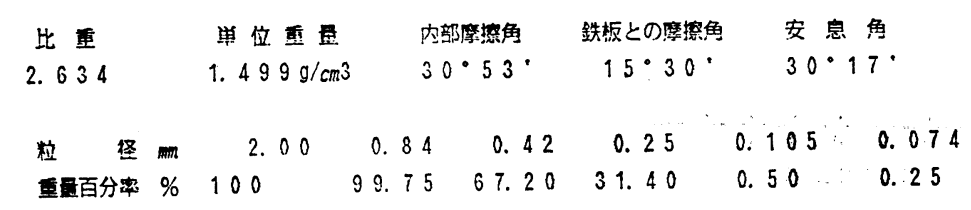




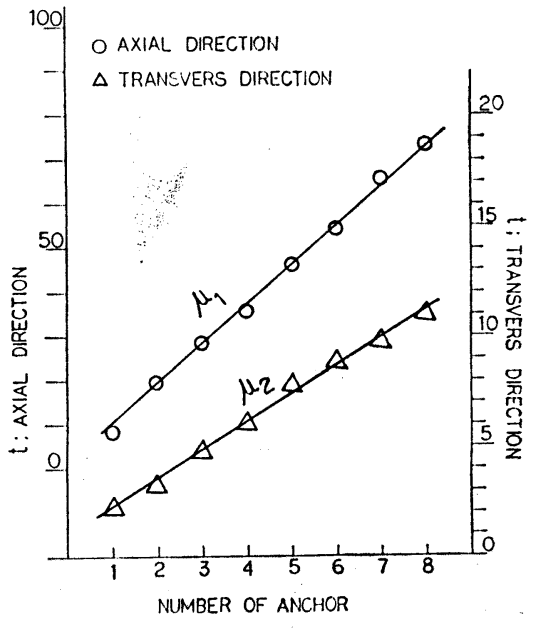

Fig. $5 \mu_{1}, \mu_{2}$ A-Type

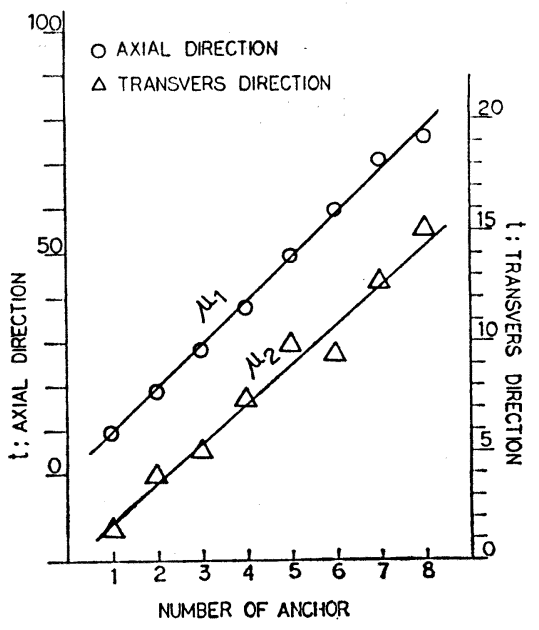

Fig. $6 \mu_{1}, \mu_{2}$, B-Type 人-Form

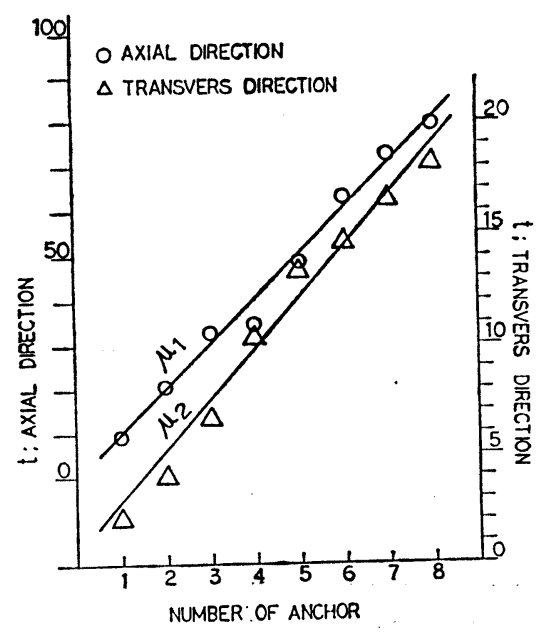

Fig. $7 \mu_{1}, \mu_{2}$, B-Type $\prec-$ Form

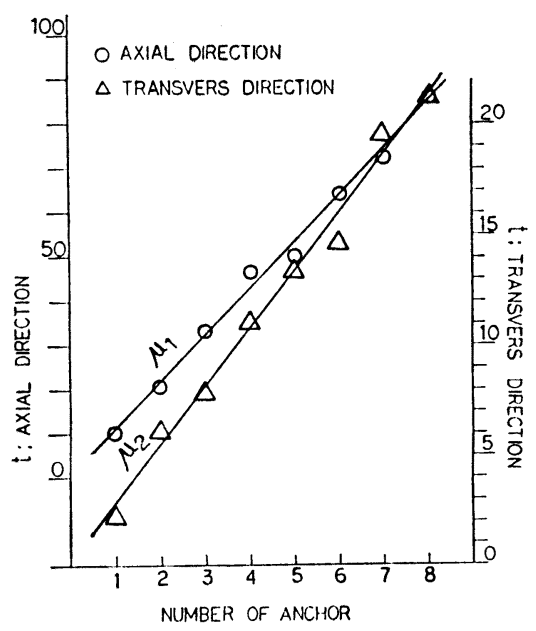

Fig. $8 \mu_{1}, \mu_{2}$, B-Type $Y$-Form

砂に対し人状のときが $\mu_{1}=9.920, \mu_{2}=1.835$, 〈状の ときが $\mu_{1}=10.156, \mu_{2}=2.309$, Y状のときが $\mu_{1}=$ 10. 578, $\mu_{2}=2.643$, である。 $\mathrm{B}$ 型の数值計算には, 各 状態の $\mu_{1}, \mu_{2}$ の平均值を使用している。

\section{3 数值計算およひ电引試験}

以上の実験からまとまった $\mu_{1}, \mu_{2}$ を用い, また単位 長さ $l$ は 1 個の小アンカーのシャンクの長さと連結用釣 系の合計長さを, 単位重量 $w$ は小アンカー 1 個の空中重 量を用い，(10)，(11)，（12）式を各 $\theta$ および $t$ につい て数值計算を行い, $t_{0}, s$ を求めた。これをグラフに表 わしたものが Fig. 9, Fig. 10 である。曳引角度が最始 の状態より $\mathrm{A}$ 型で約 $40^{\circ}$, B 型で約 $50^{\circ}$ を超えると $t_{0}$ はほとんど0になる。またそれ以下の角度です $t_{0}$ によ る把駐力を考虑すると, 曳引力に対する把駐力の必要長 さは同一であることが分かる。

次に模型アンカーの电引試験を行い計算値との比較を 行った。実験は Fig. 3 の実験装㯰を用い, 模型アンカ ーをベースラインに平行に固いた状態から，曳引点を移 動させることにより角度を変化させて計測を行ってい る。計測は十分砂をかき込んでおりかつ各小アンカーの 間には張力が働いてない状態から曳き始め，次々に張力 が加わり始める小アンカーの数で $s$ を確認し，原点の位 固はベースラインから角度がつき始める位眉を模型フン カーが回転を始める所として確認した。 $t_{0}$ は小アンカ 一と小アンカーの間にロードセルを取り付け各位置の張 力を計測している。

以上により計測した值を Table 2 に示す。 $\theta$ につい

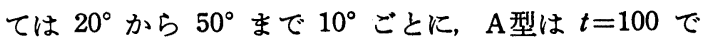
B型は $t=150$ で計測を行った。また $\theta=40^{\circ}$ で, $\mathrm{A}$ 型 は $t=25,50,75, \mathrm{~B}$ 型は $t=50,100$,でも計測してい る。実際の計測值は表に示すとおり狙った值と多少ずれ 
Table 2 Result of experiment

\begin{tabular}{|c|c|c|c|c|c|c|}
\hline & Exper & $m \in n t$ & & & Calcu & \\
\hline & & & & De & & \\
\hline$\theta$ & $\theta$ & $\mathrm{t}$ & s & $t_{0}$ & s & $t_{0}$ \\
\hline $20^{\circ}$ & $20.0^{\circ}$ & 99.1 & 9 & 7. 1 & 9. 9 & 7. 9 \\
\hline $30^{\circ}$ & $30.5^{\circ}$ & 101.0 & 11 & 8.7 & 10.7 & 2. 1 \\
\hline $40^{\circ}$ & $40.0^{\circ}$ & 24.7 & 3 & 2. 1 & 2. 7 & 0.2 \\
\hline & $40.5^{\circ}$ & 49.9 & 6 & 2. 1 & 5.4 & 0.3 \\
\hline & $41.0^{\circ}$ & 79.9 & 9 & 4. 9 & 8. 6 & 0.4 \\
\hline & $40.5^{\circ}$ & 94.3 & 10 & 7. 8 & 10.2 & 0.6 \\
\hline $50^{\circ}$ & $50.5^{\circ}$ & 96.4 & 10. & 4. 3 & 10.4 & 0.2 \\
\hline & & & & $y \mathrm{De}$ & & \\
\hline$\theta$ & $\theta$ & $t$ & $s$ & $t_{0}$ & s. & $t_{0}$ \\
\hline $20^{\circ}$ & 19. $5^{\bullet}$ & 150.2 & 12. & 28.0 & 11.5 & 32. 3 \\
\hline $30^{\circ}$ & $29.0^{\circ}$ & 147.3 & $13^{\circ}$ & 9.0 & 13.0 & 15.0 \\
\hline $40^{\circ}$ & $40.0^{\circ}$ & 51.9 & 4 & 4. 4 & 4. 9 & 2. 2 \\
\hline & $41.5^{\circ}$ & 104.8 & 10 & 1. 2 & 9. 9 & 4. 0 \\
\hline & $40.0^{\circ}$ & 156.2 & 14 & 6.5 & 14. 6 & 6. 7 \\
\hline $50^{\circ}$ & $49.5^{\circ}$ & 161.2 & 17 & 9. 9 & 15.5 & 3. 3 \\
\hline
\end{tabular}

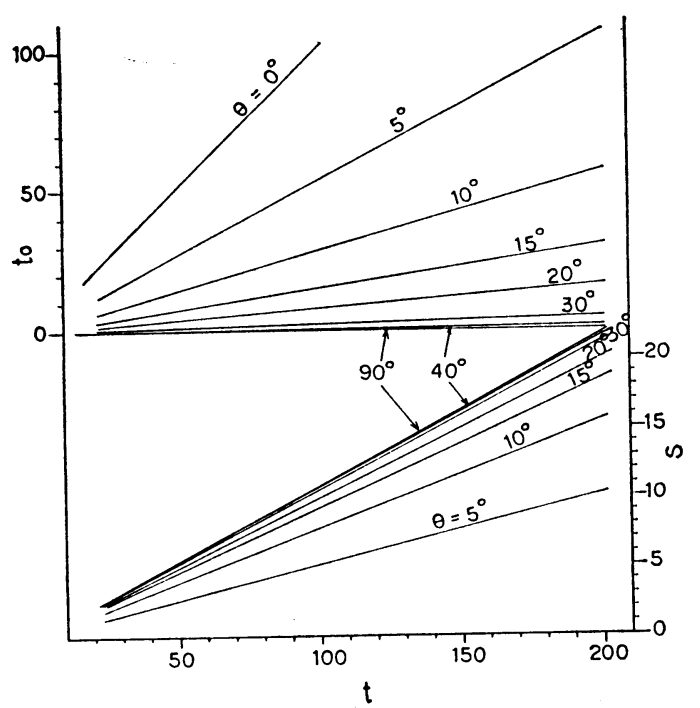

Fig. 9 S, to A-Type

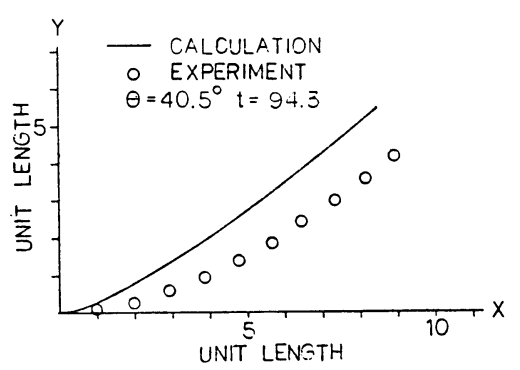

Fig. 11 Tandem type anchor form A-Type

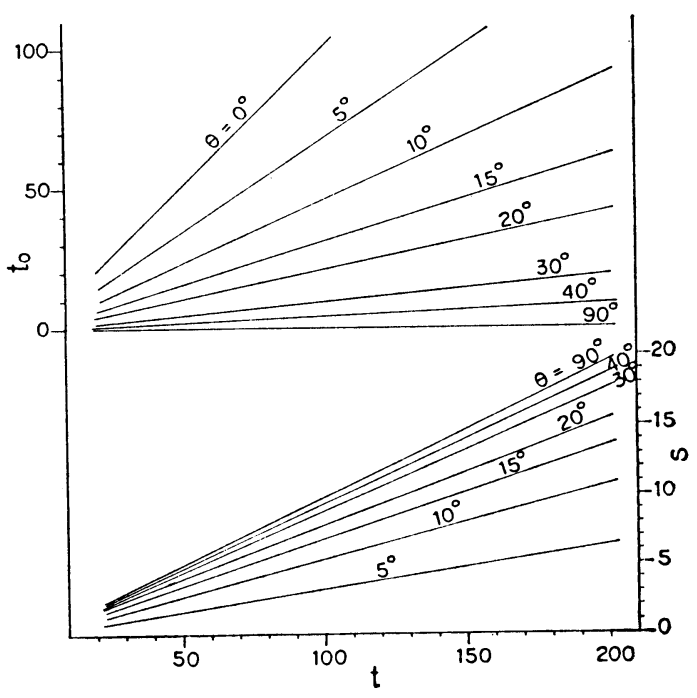

Fig. $10 \mathrm{~S}$, to B-Type

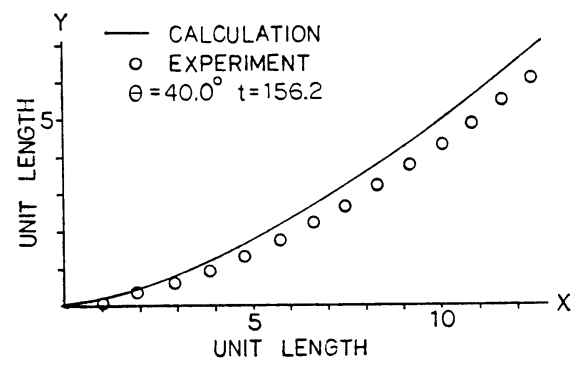

Fig. 12 Tandem type anchor form B-Type 
ているが，表に示す計算値は実際の計測值に対するるの である。またその内 $\theta=40^{\circ}$ で $\mathrm{A}$ 型は $t=100, \mathrm{~B}$ 型は $t$ $=150$ のものについて电引されたときの型を計算值と計 測値の比較をし Fig. 11，Fig. 12 に示している。

\section{5 結。}

\section{宫}

海底に横たわったタンデム式アンカーで構成される係 留ラインについて, 史引力に対する把駐力, 必要長さ, 型の計算式を導くとともに，乾燥砂中における 2 種類の 模型アンカーについて実験により明らかにした。

今回は乾燥砂中での検討であるが，海底においても抗 力係数, 重量等を適切にえらべば同様な取り扱いが出来 るものと思われる。数式について社曲線として近似した が小フンカーの数が少ない時のように, 小アンカーの結
合部で折れ曲った折線としての取り扱いが必要な場合に ついては今後の課題である。

最後に砂の性質について調查していたたいた大分工業 高等専門学校土木工学科長友教授.ならびに貴重な批評 と実験の協力をいたたいた当設計部の皆樣に厚く御礼を 申し上げます。

\section{参考文 献}

1) 浦 環：フンカーの安定性比関する基碟的研究, 日本造船学会論文集 第 140 号（昭和 51 年 11 月） p. $279 \sim 285$.

2）野村士平，鞠谷宏士：矩形板の把駐力について. 日本航海学会論文集 49 号（昭和 48 年 7 月） p. 7 17. 